\title{
Walking, Witnessing, Mapping: An Interview with Iain Sinclair
}

David Cooper and Les Roberts

Les Roberts (LR): In Lights Out for the Territory (2003: 142) you write: 'We have to recognise the fundamental untrustworthiness of maps: they are always pressure group publications. They represent special pleading on behalf of some quango with a subversive agenda, something to sell. Maps are a futile compromise between information and knowledge. They require a powerful dose of fiction to bring them to life.' In what ways do maps and mapping practices inform your work as a writer?

Iain Sinclair (IS): What I've done from the start, I think, has been to try, linguistically, to create maps: my purpose, my point, has always been to create a map of somewhere by which I would know not only myself but a landscape and a place. When I call it a 'map', it is a very generalised form of a scrapbook or a cabinet of curiosities that includes written texts and a lot of photographs. I have what could be a map of the world made entirely of these hundreds and hundreds of snapshots that aren't aesthetically wonderful, necessarily, but are a kind of logging of information, seeing the same things over and over again and creating plural maps that exist in all kinds of times and at the same time. It's not a sense of a map that wants to sell something or to present a particular agenda of any kind; it's a series of structures that don't really take on any other form of description.

[FIGURE 1 ABOUT HERE]

Figure 1. Map of London from Lud Heat (1975) (Courtesy of Iain Sinclair). 
The map [Figure 1] in Lud Heat (1975) is a good starting-point as this is supposedly the book in which I discover my own method. This map, which was drawn by the graphic designer and artist, Dave McKean, is a good version of what I am talking about as it's a kind of poetic map of all sorts of eccentric things that include cod Egyptian terms, and lines of force which E. O. Gordon describes in her book Prehistoric London: Its Mounds and Circles (1914), so that a place on Parliament Hill connects up with a Hawksmoor church. So London is knowable because it is mapped and this particular structure then goes on to not only inform what I was doing, but Peter Ackroyd, let's say, in Hawksmoor (1985), develops this notion into a Gothic novel; Alan Moore's From Hell (1991-6) actually carries on the mapping process and that goes on until it becomes a film. So in a way, even if it was only a crazy chart which was buried somewhere as in an Edgar Allan Poe story, this becomes the real starting-point for looking at the energies of London and goes through to the maps that you might find in Rodinsky. ${ }^{1}$

David Cooper (DC): You describe the McKean map from Lud Heat as 'kind of poetic map'. What are your thoughts as to what the relationship between poetry - as distinct from fiction and non-fiction writing - and cartography actually is?

IS: For me, the relationship is very close as a lot of the poetry I was doing, in the first instance, was about making a chart - a temperature chart - of a particular landscape by recalling my own movements across a space, my accidental collisions with different life-forms and different cultural memories and very often memories of film. I think film became my main method of mapping at that point in the $1960 \mathrm{~s}$. After 
studying at film school I made this film about Allen Ginsberg, then abandoned that, and just with a cheap $8 \mathrm{~mm}$ camera off the market, when I was first living in Hackney, started recording my life and the life of this community in which I was living in film silent film - just as a kind of record. But, absolutely, as a form of mapping. Walks were undertaken, for example, from where I lived right up the Lea valley: the kind of thing that was done years later in London Orbital (2003). Shot on single 8 rather than super 8. It had a single frame aspect to it so that you could just click as if you were taking still photographs; so, on this journey, a three minute chunk of film would actually represent a considerable quantity of still images that would flicker, flicker, flicker through. So it's a massing of information that is, on one sense, purely documentary; it's recording this landscape and its oddities that we've passed through. But, on another sense, it is also to do with a sort of temperature of excitement - a great face, what a beautiful colour, what a strange encounter: all of these things go into a map in a way that it wouldn't be allowed to be if I was actually a topographer, really doing a proper map. It's much more like those medieval maps you see where the things that are important are drawn large, so that you have a huge church and a tiny street: a Mappa Mundi, with demons. Obviously, at the same point I was trying to do that, I was starting to read the epic poems of William Blake, 'Jerusalem' and so on, and realised that these are also cartographic: he lists names of places and turns them into forms of energy and creates his own world-system and actually draws maps and plans of imaginary cities that are four-fold and which have huge symbolic values.

DC: Coleridge, throughout his Notebooks, adopts an analogous method based upon walking through the landscape and developing a mode of conscious witnessing. 
Coleridge is also habitually drawn to the cartographic image which seems to offer a further Romantic resonance with your own work.

IS: He's stealing. Or is he? He is plagiarising huge amounts of German material and De Quincey accuses him of this and it becomes a very complex argument as to what is your own material. Is it authentic to map a form of German literature and philosophy for re-sale in England? Both Coleridge and De Quincey, of course, were laudanum addicts, so it's a very strange superimposition on the English landscape and an argument that goes on about what is authentic, what is faked, what is pastiche, what is stolen. So, to actually see a book in which this process is beginning to happen and with the hand-written thing looking like a map because the text sort of swirls right around the printed page like a border decoration: it's rather beautiful.

LR: Brian Baker has made the following comment about your work: 'Companions seemingly walk empty pavements decoding the urban fabric but not part of the mass urban transits that make up much of the traffic of the city' (2007: 20). I was wondering what you think of that as an observation.

IS: I think that there's certainly, probably, a Romantic or sentimental attraction to the figure who is outside the mass movement of the city because the mass movement of the city is obviously strategic: we're all going off to work and the one person who is actually going in the opposite direction is not going to work. Well, he is working, but his work is wandering out into some obscure corner of the city to register some kind of sense-impression or to dig out some other story. 
LR: As with Poe's 'The Man of the Crowd', there's a sense of that mass movement of the city to which you refer; but, more importantly, an image of a solitary figure within that crowd.

IS: Exactly. It's very like that and I think that does go back to De Quincey. Again, because of his addictions and because of his determination to endlessly tear material out of himself, to support himself, and the fact he's running away from people he owes money to. In Edinburgh, there are fantastic images of him like a ghost: he can only come out at 6.30 at night when it's getting dark and the bailiffs are waiting for him and they follow him and he has to go through more and more obscure parks and scurry around faster and faster. When they say to him, 'are you De Quincey', he says 'no' and invents all of these strange pseudonyms for himself. He becomes a kind of ghost haunting himself and haunting the city; and that develops a cartography whereby the city is seen as a maze and, in Edinburgh's case, a subterranean maze as you have the under-city as well, and it's a high city as they built right up into the rock. So, he can kind of disappear upwards or along. I think that is how you map a city: by flight and by debt and by addiction.

DC: I wonder if De Quincey's disturbed imaginative mapping of Edinburgh might chime with the Ordnance Survey's (OS) emerging interest in what they call vernacular geographies...

IS: ...but OS maps lie. In Ghost Milk (2011), I wanted to walk from the mouth of the Thames to Oxford. I had to be at the absolute mouth of the Thames which is a stone called the London Stone on the south side, on the Kentish side, and another stone 
called the Crow's Stone. Both are obelisks. I looked at the OS map and here it is on the corner of the Isle of Grain by the Yantlet Creek; you can park the car in Grain and you can just walk along the beach and here it is. But when you come to the actual land you can't because it's MoD [Ministry of Defence] land. That's not put on the Ordnance Survey maps, so you suddenly hit huge concrete barriers and fences and there's no way to it. So I became really obsessed because I thought that I can't do this walk until I actually start at the very, very spot. I started just the other side of the Creek, which is only a short distance away, but it symbolically had to be that stone. So it took me about six different attempts to actually get to it; I finally got someone with a kayak but the tide was completely out that morning so we just walked across, in the end, but it was forbidden land. For the M25 project [London Orbital], there was a whole load of stuff that I wanted from the OS map but I found it to be completely fictional. So, they [the Ordnance Survey] take decisions as to what they should bring in that people want.

DC: I wonder, then, if - through their work on vernacular geographies - they're trying to be more open about the necessarily subjective, and selective, nature of mapmaking?

IS: You think that the OS could put some symbol on a map even if they aren't going to admit what it is: that this is territory that you're not going to be able to go through. But they don't even do that a lot of the time. Maps also change, of course. Waltham Abbey had these gunpowder mills but these weren't clearly shown on old OS maps. But now it's turned into a heritage site: you can buy a ticket and you can go through. So now it has to be showcased; its status on the map has gone from forbidden and 
invisible to being actually a desirable place to visit. It just depends when you buy the map.

LR: Many artists and others have started to exploit the potential offered by digital mapping technologies, whether GIS, Google maps, GPS/locational media and so on. Could you see an application for these technologies in your own work?

IS: I am sure there is. They're not technologies I use myself; but I am quite sure that, absolutely, people are doing very interesting things with digital mapping. I've come across them. People use strange tracing devices and re-map in a way that's almost like Expressionist paintings. There's a woman who managed to register - I think through some sort of satellite navigation form - everywhere she walked in a particular pattern as she went on a journey towards Antarctica. It looked like a wonderful, swirling, abstract Expressionist painting - sweeping out of this village always in circles - and I think this hinterland between these two things [art practices and geo-spatial technologies] is going to throw up major forms.

There's so much of it. There are projects along the M11 motorway [which runs north to near Cambridge from the north east of London] where whole communities and streets were obliterated when they were building the motorway; and there are now walks you can do going along there in which the voices of the people who live there will be triggered as you move through the landscapes. Or the Janet Cardiff ones which take you out of a library in Whitechapel and you follow a particular pattern through the streets: a mapped route she has done, except that she's imposing the narrative. Sometimes it coincides perfectly, so that you look down and see an orange peel or 
whatever and there it is; but sometimes it goes out of sync because you walk too fast and you arrive in Liverpool Street Station and there's this swirl.

LR: I'm interested in how these more subversive mappings become appropriated as part of other geographies and itineraries, particularly those linked to tourism, for example.

IS: It's a wonderful process. As I was saying, this kind of completely nutty map [from Lud Heat - see Figure 1] did get culturally appropriated into forms that made it popular and into a device which people were using. There are all kinds of versions of that running about. However nutty a vision you have, and you come up with yourself doodling on a piece of paper, it's quite likely to take a form because somebody is going to exploit it. Take Wyndham Lewis and the 1919 Caliph's Design, for example - the fable that started out is that there is this Caliph sitting there and he has a bit of paper when he's in bed in the morning and he just starts to do Vorticist drawings. When his architects turn up to see him he says 'go and build it'. They say: 'What? We can't!' He says: 'Well, either you build it by tomorrow or you're executed'. So, actually they do go out and, within this length of time, these strange structures have been made absolute and there they are outside the window. It's a good parable.

LR: Patrick Keiller (2003) argues that psychogeography has in many respects become an end in itself, and that instead of avant garde architecture we're now more likely to have the Time Out Book of London Walks. When do you think walking becomes just a niche form of tourism as opposed to a form of urban archaeology or however you might want to describe it? 
IS: Very definitely it has. It's one of the reasons I hate 'doing a walk'. They say: 'well, you know, you walk all the time, will you “do a walk”?' Well, I won't; not just because I'm being bloody-minded but because the whole process is like a kind of dreaming where I'm letting stuff come in and, as you're walking along if you're actually having to say 'well, now . . . here is this', it's absolutely hellish, it would be awful, it would be the exact opposite of what the experience is supposed to be which is like a forgetting and an absorbing and an emptying-out and a letting-things-happen.

\section{[FIGURE 2 ABOUT HERE]}

Figure 2. Map of Hackney from dust jacket of Hackney, That Rose-Red Empire (2009). Map illustrated by David Atkinson, Hand Made Maps Ltd (courtesy of Hamish Hamilton).

DC: At the end of Hackney, That Rose-Red Empire (2009 - see Figure 2), you walk with Robert Macfarlane whom I know has an interest in the American writer, William Least Heat-Moon, and the idea of 'deep mapping'. I was just wondering whether that concept meant anything to you?

IS: There's a close concept called 'deep topography'. This was coined by Nick Papadimitriou who lives on the fringes of west London and who has made it his business to do a deep topography of that landscape over many years; scavenging up bits of metal and things he finds on his trips and bringing them back to the house and writing in depth and in detail. He's very determined that the psychogeography term 
doesn't play. Instead, he wants to call it 'deep topography' which is a kind of a form of surveying and archiving and curating and recovering histories from finding books and talking to people or whatever in a totally obsessive way and I felt sympathetic to that. He's taken up by Russell Brand and Will Self because they respond, I think, to the deepness; it's not shallow topography but deep mapping. It's obsessively concerned with the Middlesex boundary which goes back into his personal history of some difficult childhood, psychiatric breakdowns, prisons. It was all here. It has a remedial aspect to it and his healing process is to teach himself everything he can about that landscape and to visibly settle on the edge. Then comes the question of 'where is the edge'? I was speaking to someone about that who had done a $\mathrm{PhD}$ about the edgeland, the borderland; and, say, he had been writing about the Lower Lea Valley as an edgeland, well it isn't any more. So where does your edgeland go? If this thing represented the edge of the imagination as far as you feel industrial dereliction suddenly becomes a big public park, then the edge has to dissolve somewhere else. The edge is a slippery concept to hold onto. Edgelands are very trendy, thematic territory to think about; but it's quite a hard one to define because once you start writing about it as an edgeland, and describing it so, it's actually not there.

LR: A lot of your work is collaborative and you work with filmmakers and photographers. Can you say a bit about how that feeds into what you're doing and how integral such collaborations are to your work as a writer?

IS: As an extension of the mapping process, I felt quite strongly that it was good to be involved with different kinds of cultural practice. I was always drawn to filmmakers or photographers who would, by coming on the expeditions I was making, offer a 
two-fold advantage: one, that I'd have a kind of record of a different order because of the images they were making; but also because their practice didn't have any particular interest in the histories I was narrating. They would listen to the stories and the stuff I was telling them and maybe these would influence the photographs they were taking in some way. I would also have a sounding-board; I would have a kind of character in terms of the narrative I was telling, beyond the single self and the ego of the self moving through a landscape as all-seeing. There was a challenge in a photographer looking at it in a different way. Or, with the M25, obviously, Chris Petit's great thing has been as a kind of road-movie, the idea of being in a car, the world as the screen of the car, cinema screen; very cool in practice, slightly Germanic, everything laid out. Whereas mine, there's an overlying torrent of images and ideas bursting out in every direction; so this disciplined thing was a good filter on what I was doing. So I like the process very, very much; and, also, I'm quite drawn to doing public versions of the books as a real tester. So, as with the London Orbital event at the Barbican in $2002^{2}$, the idea is that there is music and film and performance all drawn off from what is a text or a script which is the thing I've written.

LR: In Agnes Varda's film, The Gleaners and I (2000) she extends the metaphor of 'gleaning' to the filmmaking process, so that her DV camera becomes almost like a collecting sack: she is going out there, picking things up and collecting it as she goes along, which lends a real materiality to the art of image-making. That seems to resonate particularly with the work you've done with Chris Petit.

IS: There was a process with Chris on things like London Orbital where we, separately a lot, were just going out gleaning and bringing back stuff on these 
expeditions, trawling and scavenging, and, then sitting down in a cutting-room. That was the process which was exactly like writing a book because we had piles of stuff and you were throwing this bit against that bit and then splitting the screen; and I had my bit and he had his bit and the two voices creating a narrative. It is a way you can't really work in film because it's not economically viable. Essentially, we probably spent four or five months just in the process of editing which became the entire construction; and, if there were things you didn't want in terms of how the thing looked, then you could actually re-film in the editing suite and use that as your grammar. Whereas in the early experience I had of film there would be missing shots: you couldn't put a sequence together as we didn't have someone coming through the door, for example, and you had to do dissolves or cut-aways. That all goes out of the window; you don't have to do that because of the new technology.

DC: We've been wondering whether there's a danger of the over-use of the idea of mapping in the arts and humanities. So, in literary criticism, for example, you get a lot of critics pledging to 'map' a poem or a novel when they're basically offering good, old-fashioned critical practice. Do you feel that the verb 'to map' has become exhausted?

IS: I think it was getting a bit tired maybe four or five years ago. I remember that there was a huge vogue. There were a series of conferences and things going on about mapping; and then it drifted off. I think that, coming back now, it's quite re-energised as a term; there's a lot going on because technology allows you to do these things that we've been talking about that are more interesting. It isn't just a conceit, I don't think, and I've found that geographers and architects, as it were those general disciplines, 
are much more interested in the literary or poetic imagination than any English departments; it's very rare that I get asked to go anywhere near an English department. So, therefore, what are people drawing on? They are drawing on forms of memory, language, mapping, anthropology, and wanting to dissolve the boundaries that have held these to a rigid scholarly discipline.

DC: Picking up on ideas of dissolution and liquidity, I am struck by the way in which the concept of 'floating' recurs in your writing; and there's one point, in Edge of the Orison (2005), where you talk about a 'floating autobiography'. I was left wondering: what is that exactly?

IS: Who knows? Exactly. With the John Clare book - in which I use those terms 'Walking', 'Dreaming', 'Floating', 'Drowning' - I am concerned, absolutely, with mapping the topography: a complex mapping because it starts with a very specific map which you get in books of Clare's own journey in which he walks up what he thinks is the Great North Road and walks to Peterborough. It is actually a road map. And then I set off to reprise this. You can't follow his movement exactly, it detours; so you can have a second map. And then, by doing it, realizing that I can't follow the neural grooves of the John Clare map - although I touch them because you sleep at the same spots and connect with places he writes about - a process happens that throws up something else in terms of landscape, realizing that there is this thing, like Whittlesey Mere [in the Cambridgeshire Fens], which was this huge inland lake which was drained: because it's not there it creates a very mysterious space on a map. It isn't on the map because it's not there; but, if you go there, it is there and you get a sense of a piece of geography that exists in a world that isn't real and isn't deep topography but 
is floating because it's in the mind, it's in the memory, it's in the imagination and it haunts that part of the world. So, then I would say that the procedures in that book that were to do with being out of your depth for one reason or another and drowning: whether literally, as with Shelley and so on; or Clare feeling that he tumbles into a river as a child, those literal senses of drowning and a sense of walking as a form of retrieval and healing and discovery. It's rather like Werner Herzog's walk from Munich to Paris: he's going to heal a friend of his by completing this mad journey on foot.

DC: I heard you once talk about Clare being an actual, as well as ghostly, presence as you retraced his walk. So, there's an imbrication of those two ideas: the ethereal nature of floating; and a real sense of materiality.

IS: There's a real presence, a real human entity and an archetype - which I've always been attracted to - of the figure on the road like John Bunyan, Jack Kerouac, whatever you want. Someone struggling in having a difficult time physically - feet sore, foot foundered, wrecked, no money, chewing tobacco - and achieving vision through that, achieving some great sense of imaginative breakthrough which Clare seems to get along the way. But it's all grim because the woman he thinks he can conjure back into life who has died doesn't reappear and the real wife does appear; he can't live with this double image, he goes into Northampton Asylum and spends the rest of his life there. Same place that Lucia Joyce ${ }^{3}$ is going to end up in years later, for much longer, and who writes a lot about drowning and this connects up with Samuel Beckett who is visiting her and who is an obsessive swimmer and the whole thing in Finnegans Wake about drowning and the River Liffey being absorbed into the sea. So, all of that 
meshes together in a way that starts with a very, very simple map; with going from A to B. If you do go from A to B and, if it's tough enough, then the whole world opens out from it.

\section{[FIGURE 3 ABOUT HERE]}

Figure 3. Annotated tube map from David Rodinsky's A to $Z$ of London. Reproduced in Dark Lanthorns (1999) (courtesy of Iain Sinclair \& Em Goldmark).

LR: In Dark Lanthorns (1999) you re-trace David Rodinsky's ${ }^{4}$ wanderings around London and Essex. In this example the map as artefact - Rodinsky's $A$ to $Z$ of London - forms the basis for a fictional biography and initiates a sort of detective trail.

IS: I had written a totally fictional version of Rodinsky before this in Downriver (2006/1991); but the actual Rodinsky project was, of course, the basis of Rachel Lichenstein's research and was completely authentic (Lichenstein and Sinclair 2000). But the thing was: here is this room, absolutely jammed with stuff. How do you pull together a story, a detective story? Can you recreate this man from these objects and things which may or may not actually have been his? I always look at London $A$ to $Z$ 's and there was this one amongst all this tons and tons of stuff in that room (Figure 3). That interested me a lot because they're very friable, the pages come apart if you look at it. And then, as with Coleridge's Notebooks, you see annotations: Rodinsky had actually marked these journeys. There weren't that many but what did they mean? They were quite bizarre. They took me out to Dagenham. Why on earth would he go round these particular patterns of streets? So, following that, gradually it does emerge 
that, yes, he was sent away to Dagenham as a child, so this actually represents a period in his life. But did he then, in some future date, try to remember his own childhood and draw a map upon that page? And then there's one that led out to Claybury $^{5}$ where it turns out his sister was in this asylum for many, many years; but he never, according to the maps on the $A$ to $Z$, quite got there, he always got to the foot of it. Could he not bring himself to go up and see her? Who knows? I think that the maps, because there were the three principal maps, were things that were really important to him and that he possibly went back to Dagenham to try to see where he had been as a young kid. I think he'd been back to Claybury after he had abandoned the idea of getting there. He'd just done some bus trip and I think the lines were a record of the journey he made rather than plotting. It might have been plotting where he should go; but they were so random, going off into strange things, that I think that it represented a journey that he made. So, it was a map; a pure map in terms of being superimposed upon a very standard artefact, customised.

Just after that Rodinsky project - it might have been before - I met somebody called Keggie Carew who had a gallery in Redchurch Street in London ${ }^{6}$; and she said that I've been reading your books - I think, actually, she had been reading Lud Heatand would you like to have an exhibition in this gallery? And I had just that day bought an AA map: a map of London for drivers and I thought that it would be really interesting to subvert that and to only use it for walking. I asked seven or eight different people if I could send them this AA road map of London, they would look through these and make a mark on one of them at random and then send them back to me. I would walk to wherever it was that they had marked up and I would keep a photographic record and write some stuff and then I would make these sheets which were images of my walk and text. Then they, themselves, would have to contribute an 
artwork or an image or an artefact or something relating to their idea of what I would be doing - anything they like - and we would hang them together. I would also, on a plinth, put an object or a book or anything I would find along the way of this journey in the way that I would do if I was writing about it. Some of the walks were quite epic and some of them were very short and some of them were obviously people had just [randomly selected a site] and other ones they wanted me to see something which meant a lot to them but which did not necessarily mean anything to me. Chris Petit, Dave McKean, Marina Warner, Alan Moore, Brian Catling, Marc Atkins I think: a big spectrum of people did this and the objects, or artworks, that they themselves presented were equally interesting. It was a complete mapping.

\section{Notes}

\section{References}

Baker, B. 2007. Iain Sinclair. Manchester: Manchester University Press.

Gordon, E. O. 1914. Prehistoric London: Its Mounds and Circles. London: Elliot Stock.

Herzog, W. 1991. Of Walking in Ice: Munich - Paris 23 November - 14 December 1974. London: Jonathan Cape.

Keiller, P. 2003. 'City of the Future', in City 7 (3): 376-386. 
Lewis, W. 1919. The Caliph's Design. Architects! Where is Your Vortex? London: The Egoist.

Lichenstein, R. and Sinclair, I. 2000. Rodinsky's Room. London: Granta.

Schloss, C. L. 2004. Lucia Joyce: To Dance in the Wake. London: Bloomsbury.

Sinclair, I. 1975. Lud Heat: A book of the Dead Hamlets. London: Albion Village Press. [re-published in 1998 as Lud Heat and Suicide Bridge. London: Granta]

Sinclair, I. 1999. Dark Lanthorns: Rodinsky's A to Z. Uppingham: Goldmark.

Sinclair, I. 2003 [1997]. Lights out for the Territory. London: Penguin.

Sinclair, I. 2003. London Orbital: A Walk Around the M25. London: Penguin.

Sinclair, I. 2005. Edge of the Orison: In the Traces of John Clare's 'Journey Out of Essex'. London: Penguin.

Sinclair, I. 2006 [1991]. Downriver. London: Penguin.

Sinclair, I. 2009. Hackney, That Rose-Red Empire: A Confidential Report. London: Hamish Hamilton. 
Sinclair, I. 2011. Ghost Milk: Calling Time on the Grand Project. London: Hamish Hamilton. 
1 See Dark Lanthorns (Sinclair 1999) and Rodinsky's Room (Lichenstein and Sinclair 2000).

2 'Iain Sinclair's M25 London Orbital', The Barbican Centre, London, 25 October 2002. Described as a 'parallelist performance in three-lane theatre' the event featured readings by Sinclair, Bill Drummond, Ken Campbell, music from Wire, and a triptych screening of film of the M25 shot by Chris Petit.

3 Lucia Joyce (1907-82) was the daughter of the great Irish modernist, James Joyce, and Nora Barnacle. A former lover of Beckett, Lucia Joyce was diagnosed with schizophrenia and, in 1936, was placed in an institution in the commune of Ivry-sur-Seine, Paris. In 1951, she was sent to St Andrew's Hospital, Northampton, where she died thirty-one years later. See Schloss (2004).

4 See also Lichenstein and Sinclair (2000). Rodinsky was a reclusive Jewish scholar who in 1969 vanished without trace from his home above a disused synagogue in the east end of London. The room and possessions he left behind (including an $\mathrm{A}$ to $\mathrm{Z}$ atlas of London) was discovered in 1980 .

5 Claybury Asylum, a Victorian psychiatric hospital in Essex which closed in 1997.

6 See www.iainsinclair.org.uk/2010/11/28/a-magical-space-at-73-redchurch-street-e2/ (accessed 6 June 2011). 